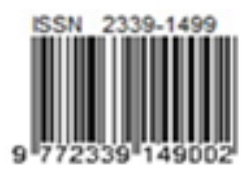

\title{
Pengembangan Model Blood Mobile Collection Routing Problem (BMCRP) pada Proses Pengumpulan Darah
}

\author{
Titi Iswari ${ }^{*}$, Fran Setiawan ${ }^{2}$, Carles Sitompul ${ }^{3}$ \\ 1,2,3) Fakultas Teknologi Industri, Jurusan Teknik Industri, Universitas Katolik Parahyangan \\ Jl. Ciumbuleuit 94, Bandung 40141 \\ Email: 1)titiiswari@unpar.ac.id, 2)fransetiawan@unpar.ac.id, ${ }^{3)}$ carles@unpar.ac.id
}

\begin{abstract}
This research develop a model of blood mobile collection using blood donor vehicle efficiently by determining the optimal route of blood collection to the points of blood collection. The model developed in the form of mixed integer nonlinear programming (MINLP) and this model is called Blood Mobile Collection Routing Problem (BMCRP). The purpose of this model is to minimize the total distance of the blood collection routing process in which each place of blood collection has the opening hours and the closing time (time windows) and the service time in each place. This study considers the blood age (spoilage time) for 6 hours to ensure blood quality. The mathematical model is then verified to determine whether the solution is in accordance with the characteristics of BMCRP. Verification is done by solving Blood Mobile Collection Routing small cases. The simulation of solving BMCRP is done by generating eight hypothetical data sets of small cases based on vehicle routing data problems with different characteristics. Verification of BMCRP uses LINGO software. From the simulation results, the BMCRP model can obtain optimal solutions with minimum total distance travelled and does not violate any constraints on BMCRP.
\end{abstract}

Keywords : blood mobile collection, routing problem, spoilage time

\begin{abstract}
Abstrak
Penelitian ini mengembangkan suatu model pengambilan darah secara mobile menggunakan mobil donor darah secara efisien yaitu dengan menentukan rute optimal pengambilan darah menuju titik-titik pengambilan darah. Model yang dikembangkan berupa mixed integer non-linear programming (MINLP) dan model ini disebut sebagai Blood Mobile Collection Routing Problem (BMCRP). Tujuan dari model ini adalah untuk meminimalkan total jarak proses pengambilan darah dimana masing-masing tempat pengambilan darah mempunyai jam buka dan jam tutup (time windows) serta adanya lama waktu singgah (service time) di masing-masing tempat. Penelitian ini memperhatikan umur darah (spoilage time) selama 6 jam untuk menjamin kualitas darah. Model yang telah dikembangkan kemudian dilakukan verifikasi dan validasi untuk mengetahui apakah solusi yang dihasilkan sudah sesuai dengan karakteristik permasalahan BMCRP. Pengujian dilakukan dengan melakukan simulasi penyelesaian kasus Blood Mobile Collection Routing. Simulasi dilakukan dengan membangkitkan 8 data set hipotetik berupa kasus kecil yang didasarkan dari data vehicle routing problem dengan karakteristik yang berbeda-beda. Penyelesaian BMCRP ini menggunakan bantuan software LINGO. Dari hasil simulasi penyelesaian kasus BMCRP didapatkan hasil bahwa model yang telah dibangun mampu memberikan solusi optimal dengan total jarak minimum dan tidak melanggar batasan-batasan pada BMCRP.
\end{abstract}

Kata kunci : blood mobile collection, rute optimal, umur darah

\section{Pendahuluan}

Tranfusi darah merupakan salah hal yang penting dalam dunia kesehatan. Tranfusi darah dapat menyelamatkan nyawa seseorang yang mengalami pendarahan, anemia, penyakit kelainan darah, pasien yang sedang dioperasi di rumah sakit dan lain-lain. Saat ini kebutuhan akan tranfusi darah pun semakin meningkat. Hal ini tidak diimbangi dengan peningkatan supplai darah yang dihasilkan. Hal ini menyebakan ketidakseimbangan antara 
penyediaan darah dan kebutuhan darah. Berdasarkan data World Health Organization, jumlah kebutuhan minimal darah di Indonesia sekitar 5.1 juta kantong pertahun yaitu $2 \%$ dari jumlah penduduk Indonesia. Produksi darah dan komponennya saat ini sebanyak 4,6 juta kantong dari 3,05 juta donasi. Dari data ini dapat dilihat bahwa masih terjadi kekurangan jumlah produksi darah secara nasional sekitar 500 ribu kantong (Kementerian Kesehatan Republik Indonesia, 2016).

Menurut Menteri Kesehatan RI, Prof. Dr. dr. Nila Farid Moeloek, Sp.M(K), kekurangan jumlah suplai darah ini dikarenakan ketersediaan darah di sarana kesehatan sangat ditentukan oleh partisipasi masyarakat dalam kesediaan mendonorkan darahnya secara sukarela. Dari jejak pendapat yang dilakukan oleh Kompas, didapatkan hasil bahwa hanya sedikit masyarakat yang masih menggiatkan kebiasaan menjadi donor darah. Hanya 7,5 persen responden yang mengaku menjadi pendonor darah rutin. Fakta ini mencerminkan belum terbentuknya kepedulian publik untuk mendonorkan darahnya. Menurut Menteri Kesehatan RI, kegiatan donor darah harus ditunjang oleh ketersediaan fasilitas, sarana dan prasarana yang dapat menjamin ketersediaan darah dalam jumlah yang cukup, aman dan berkualitas. Hal ini berarti dibutuhkannya suatu fasilitas yang dapat menunjang kemudahan masyarakat dalam melakukan donor darah yang diharapkan dapat menambah jumlah pendonor darah sukarela. Oleh karena itu, pada penelitian ini dibuat mekanisme mobil donor darah yang dapat berpindah-pindah ditempat strategis tertentu pada waktu tertentu untuk melakukan pendonoran darah (sistem mobile). Mekanisme ini perlu ditunjang dengan proses pengambilan darah yang efisien yang dapat dilakukan dengan penentuan rute optimal ke titik pengambilan darah.

Menurut peraturan dari The Food and Drug Administration (FDA) dan The American Association of Blood Banks (AABB) yang mengatur tentang proses pengumpulan darah, penyimpanan darah, dan pemrosesan darah maupun komponennya, darah yang sudah dikumpulkan harus dipisahkan menjadi komponen-komponennya dalam waktu 6 jam dan tidak lebih dari 18 jam (spoilage time) (Yi, 2003). Hal ini menyebabkan darah yang telah terkumpul pada proses donor darah harus diproses dalam waktu 6 jam setelah pengambilan karena setelah 6 jam kualitas darah akan menurun dan tidak dapat digunakan lagi setelah 18 jam.

Berdasarkan uraian di atas, penelitian ini mengembangkan suatu model pengambilan darah secara mobile menggunakan mobil donor darah secara efisien. Salah satu cara yang dapat digunakan untuk membuat proses pengambilan darah dengan efisien adalah dengan menentukan rute optimal pengambilan darah. Model ini disebut Blood Mobile Collection Routing Problem (BMCRP). Model yang dikembangkan berupa Mixed Integer Non-Linear Programming (MINLP) untuk meminimalkan total jarak proses pengambilan darah dengan memperhatikan umur darah untuk menjamin kualitas darah.

\section{Metode Penelitian}

Penelitian mengenai efisiensi dari proses pengumpulan darah telah diteliti sejak tahun 1970 (Dumas and Rabinowitz, 1977), tetapi masih sedikit yang menganalisis menggunakan vehicle routing problem seperti yang dilakukan pada penelitian kali ini. Vehicle Routing Problem (VRP) untuk proses pengumpulan darah merupakan salah satu jenis Vehicle Routing Problem with Time Windows (VRPTW) for perishable product. Hal ini dikarenakan darah juga memiliki waktu umur produk yang terbatas yaitu selama 6 jam sebelum diproses lebih lanjut (AmericanAssociation-of-Blood-Banks, 2007).

Menurut Laporte (1992), VRP dapat dideskripsikan sebagai suatu masalah untuk mendesain rute pengumpulan yang optimal dari satu atau beberapa depot ke beberapa customer dengan mempertimbangkan batasan-batasan yang ada. VRP pertama kali diperkenalkan oleh Dantzig and Ramser (1959) untuk menentukan rute optimal pada pendistribusian gasolin dari satu terminal besar ke stasiun-stasiun yang disuplai oleh terminal tersebut.

Laporte (1992) mendefinisikan VRP sebagai berikut : Diketahui $G(\mathrm{~V}, \mathrm{~A})$ dengan $\mathrm{V}=$ $\{1, \ldots . . \mathrm{n}\}$ merupakan kumpulan customer dengan demand yang yang diketahui dan deterministik. V(1) menunjukkan adanya satu depot. A merupakan kumpulan arc yang menghubungkan semua titik pelanggan. $c_{i j}$ merupakan biaya dari setiap arc antara node $i$ dan $j$. Fungsi tujuan dari VRP adalah untuk 
meminimalkan total jarak tempuh dari setiap kendaraan yang ada dengan memperhatikan batasan seperti :

1. Satu customer hanya bisa dikunjungi sekali

2. Setiap rute berawal dan berakhir pada suatu depot

3. Batasan lain yang harus dipenuhi sesuai kasus yang ada (time windows, maximum time, dII)

VRP yang paling sering ditemui adalah Capacitated Vehicle Routing Problem (CVRP). Pada CVRP, kendaraan mempunyai kapasitasnya masing-masing dan total produk yang diangkut oleh masing-masing kendaraan tidak boleh melebihi kapasitas kendaraan tersebut (Solomon, 1988). Namun pada kenyataannya, terkadang selain terdapat batasan kapasitas kendaraan, konsumen juga mungkin memiliki suatu periode waktu dimana mereka hanya bisa dilayani pada jam tersebut. Kasus ini disebut Vehicle Routing Problem with Time Windows (VRPTW) (Solomon, 1988). Selain itu, pada penelitian kali ini terdapat batasan lain yaitu adanya umur darah (spoilage time), dimana darah berada dalam perjalanan maksimal selama umur darah tersebut untuk mencegah darah menjadi rusak dan busuk. Seperti yang telah dijelaskan sebelumnya, darah merupakan salah satu produk perishable karena dapat membusuk. Salah penelitian mengenai VRP untuk produk perishable telah dilakukan oleh Song dan Ko (2016). Objek pada penelitian tersebut adalah produk makanan.

Penelitian mengenai pengumpulan darah telah dilakukan oleh beberapa peneliti. Ozener dan Ekici (2011) mengajukan model maximum blood collection problem (MBCP) untuk memaksimumkan jumlah darah yang dikumpulkan dengan mempertimbangkan ketersediaan kendaraan. Perbedaan MBCP dengan VRP adalah untuk MBCP fungsi objektifnya adalah untuk memaksimalkan jumlah darah yang dikumpulkan sehingga masing-masing titik bisa dikunjungi lebih dari sekali (Ozener dan Ekici, 2011). Selain itu terdapat juga penelitian dari Doerner, et al. (2008) yang mencari biaya minimum ketika mengumpulkan suplai darah dan menggunakan metode branch and bound untuk penyelesaiannya. Terdapat juga penelitian dari Iswari, et al (2016) mengenai blood collection routing untuk lokasi donor darah yang tetap (fix donation sites) dengan menggunakan metode simulated annealing. Untuk jenis pengumpulan darah dengan fix donation sites, kendaraan hanya mengambil darah yang telah terkumpul sebelumnya sehingga asumsinya tidak terdapat service time, sedangkan pada sistem mobile maka kendaraan akan singgah dalam waktu tertentu untuk melakukan proses pengumpulan darah, waktu singgah yang semakin lama akan membuat darah yang terkumpul semakin banyak.

Gunpinar dan Centeno pada tahun 2015 membangun model optimisasi untuk rumah sakit yang dikembangkan untuk mengelola sumber daya darah secara lebih efisien yang pada akhirnya akan menghasilkan pengurangan biaya dan peningkatan layanan bagi pasien rumah sakit. Kemudian terdapat penelitian lanjutan mengenai pengumpulan darah secara mobile oleh Gunpinar dan Centeno (2016). Penelitian dari Gunpinar dan Centeno (2016) bertujuan untuk menentukan jumlah kendaraan yang tepat dan titik-titik mana yang harus dikunjungi setiap harinya dengan meminimalkan jarak yang ditempuh. Pada penelitian dari Gunpinar dan Centeno (2016), terdapat batas maksimal jumlah titik yang bisa dikunjungi oleh kendaraan setiap harinya, tetapi tidak ada batasan time windows dari setiap nodes dan depotnya. Selain itu, batasan umur darah ditinjau dari umur suplai darah di inventori blood center yaitu 3-5 hari bukan dari umur darah saat proses pengumpulannya ke blood center (maksimum umur darah saat sampai ke blood center adalah 6 jam). Penelitian lain untuk bloodmobile dilakukan oleh Sahinyazan, et al (2015). Sahinyazan, et al (2015) mengusulkan model matematis dan algoritma heuristik 2tahap berbasis IP untuk menentukan rute dari kendaraan dan lama mereka tinggal di setiap pemberhentian. Masalah ini merupakan ekstensi dari Selective Vehicle Routing Problem.

Dari hasil studi literatur yang dilakukan, dapat dilihat bahwa penelitian mengenai proses pengumpulan darah (collection) masih sangat terbatas, terutama untuk sistem pengumpulan yang bersifat mobile. Pada penelitian kali ini terdapat batasan-batasan yang tidak terdapat pada penelitian sebelumnya yaitu time windows dan umur 
maksimal darah dari titik-titik pengumpulan hingga ke blood bank.

\section{Pengembangan Model Matematis BMCRP}

Blood Mobile Collection Routing Problem (BMCRP) merupakan sebuah permasalahan bagaimana suatu kendaraan pengumpul darah mengunjungi setiap tempat pengumpulan darah untuk meminimasi jarak yang ditempuh dengan mempertimbangkan batasan-batasan yang ada dengan sistem mobile. Proses pengumpulan darah yang bersifat mobile dalam penelitian ini mempunyai mekanisme sebagai berikut :

1. Terdapat 1 depot yang berfungsi sebagai blood bank, dimana blood bank memiliki jam buka-tutup yang spesifik.

2. Blood bank memiliki sejumlah kendaraan (shuttle) lengkap dengan peralatan untuk melakukan proses donor darah. Setiap kendaraan memiliki kapasitas maksimal untuk jumlah darah yang dapat diangkut.

3. Kendaraan dari blood bank akan mengunjungi titik-titik potensial yang telah ditentukan dan singgah pada titik tersebut pada waktu tertentu (service time) untuk melakukan proses pengumpulan darah.

4. Di setiap titik-titik potensial terdapat supply rate yang menggambarkan rata-rata jumlah darah yang dapat dikumpulkan tiap satuan waktunya. Titik-titik potensial tersebut juga memiliki jam buka-tutupnya masing-masing. Permasalahan BMCRP digambarkan sebagai sebuah jaringan tempat pemrosesan darah dengan beberapa tempat pengambilan darah. Setiap tempat pengambilan darah memiliki rate (laju) pengumpulan darah dan kendaraan mempunyai waktu singgah (service time) disetiap tempat pengambilan darah untuk mengumpulkan darah. Didalam suatu graph, permasalahan ini digambarkan sebagai jaringan beberapa titik dengan satu titik merupakan depot (tempat pemrosesan darah) dan node lain merupakan berbagai tempat pengumpulan darah. Setiap tempat pengumpulan darah memiliki jam buka dan jam tutup pelayanan yang harus dipatuhi dalam setiap pengambilan darah. Darah yang terambil memiliki spoilage time yang merupakan rentang waktu darah masih baik untuk diproses setelah darah diambil sehingga kendaraan harus tiba kembali ke tempat pemrosesan darah sebelum mencapai spoilage time dari darah yang sudah diambil.
Gambar 1. merepresentasikan model jaringan dari Blood Mobile Collection Routing Problem.

Notasi :

$N \quad=$ set dari node $\{0,1,2, \ldots, \mathrm{N}\}$

$K=$ set dari kendaraan $\{0,1,2, \ldots, K\}$

$C a p_{k}=$ kapasitas kendaraan $\mathrm{k}$

$P_{i} \quad=$ jumlah darah yang terkumpul pada node i

$D_{i j} \quad=$ jarak tempuh dari node $\mathrm{i}$ ke node $\mathrm{j}$

Dur $r_{j k}=$ waktu tempuh dari node $\mathrm{i}$ ke node $\mathrm{j}$ dengan kendaraan $\mathrm{k}$

$A_{i} \quad=$ jam buka node $\mathrm{i}$

$B_{i} \quad=$ jam tutup node $\mathrm{i}$

$S_{i} \quad=$ waktu singgah di node $\mathrm{i}$

$T_{i k} \quad=$ waktu tiba kendaraan $\mathrm{k}$ di node $\mathrm{i}$

$W_{k}=$ total waktu perjalanan kendaraan $\mathrm{k}$

$\tau \quad=$ umur darah dalam satuan waktu

$M \quad$ = bilangan bulat besar

NK = jumlah kendaraan

$U_{i k}=$ variabel tambahan yang menunjukkan beban kendaraan $\mathrm{k}$ setelah mengunjungi node $\mathrm{i}$

Variabel keputusan

$Y_{i k} \quad=$ bernilai 1 jika node $\mathrm{i}$ dikunjungi oleh kendaraan $\mathrm{k}$, 0 sebaliknya

$X_{i j k}=$ bernilai 1 jika kendaraan $\mathrm{k}$ melakukan perjalanan dari node i ke node j, 0 sebaliknya

$T_{i k} \quad=$ waktu kendaraan $\mathrm{k}$ di node i mulai dilayani

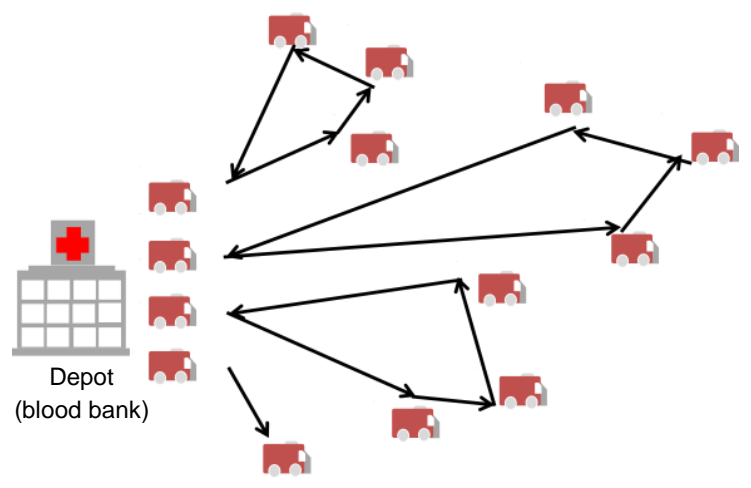

Gambar 1. Model Jaringan Blood Mobile Collection Routing

Fungsi Tujuan

Minimasi

$\sum_{i \in N} \sum_{j \in N} \sum_{k \in K} D_{i j} X_{i j k}$

Pers. 1

Kendala : 


\begin{tabular}{|c|c|c|}
\hline$\sum_{k \in K} Y_{i k}=1$ & $\forall i \in N, i \neq 0$ & Pers. 2 \\
\hline$k \in K=Y_{0 k} \leq N K$ & $k \in K$ & Pers. 3 \\
\hline 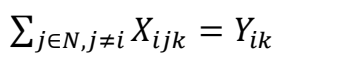 & $\forall i \in N, k \in K$ & Pers. 4 \\
\hline$\in N, i \neq j=X_{j i k}=Y_{i k}$ & $\forall j \in N, k \in K$ & Pers. 5 \\
\hline 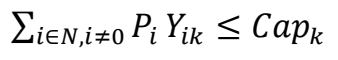 & $\forall k \in K$ & Pers. 6 \\
\hline$\leq T_{i k} \leq B_{i}$ & $\forall i \in N, k \in K$ & Pers. 7 \\
\hline$k+S_{i} \leq B_{i}$ & $\forall i \in N, k \in K$ & Pers. 8 \\
\hline \multicolumn{3}{|c|}{$T_{i k}+S_{i}+\operatorname{Dur}_{i j k}-T_{j k} \leq M\left(1-X_{i j k}\right)$} \\
\hline$A_{1} \leq W_{k} \leq B_{1}$ & $\forall k \in K$ & Pers. 10 \\
\hline \multicolumn{3}{|c|}{$\sum_{i \in N} T_{i k} X_{i 0 k}+S_{i} X_{i 0 k}+D u r_{i 0 k} X_{i 0 k}=W_{k}$} \\
\hline & $\forall k \in K$ & Pers. 11 \\
\hline$N_{k}-\sum_{j \in N} X_{1 j k} T_{j k} \leq$ & $\forall k \in K$ & Pers. 12 \\
\hline$r_{i} \leq U_{i k} \leq \operatorname{Cap}_{k} \quad \forall i \in$ & $E N, i \neq 0, k \in K$ & Pers. 13 \\
\hline $\begin{array}{r}U_{i k}-U_{j k}+\operatorname{Cap}_{k} X_{i j k} \\
\forall i, j \in N, i \neq 1, j\end{array}$ & $\begin{array}{l}\leq \operatorname{Cap}_{k}-R_{j} \\
j \neq 0, i \neq j, k \in K\end{array}$ & Pers. 14 \\
\hline$\in\{0,1\}$ & $\forall i \in N, k \in K$ & Pers. 15 \\
\hline$\in\{0,1\}$ & $\forall i, j \in N, k \in K$ & Pers. 16 \\
\hline
\end{tabular}

Fungsi tujuan Pers.1 meminimalkan total jarak tempuh kendaraan. Kendala Pers.2 memastikan bahwa suatu tempat hanya dikunjungi sekali. Kendala Pers.3 memastikan bahwa kendaraan yang keluar dari depot tidak melebihi jumlah kendaraan yang tersedia. Kendala Pers. 4 dan Pers. 5 memastikan bahwa kendaraan yang masuk dan meninggalkan suatu tempat adalah kendaraan yang sama. Kendala Pers.6 memastikan bahwa darah yang terkumpul tidak melebihi kapasitas kendaraan. Kendala Pers.7 - Pers.10 merupakan pengaturan time windows. Kendala Pers.7 memastikan bahwa kendaraan tiba disuatu tempat tidak melanggar jam buka dan jam tutup tempat tersebut. Kendala Pers.8 memastikan bahwa jam kendaraan tiba dan lamanya kendaraan singgah tidak melebihi jam tutup suatu tempat. Kendala Pers.9 memastikan bahwa waktu kendaraan mulai dilayani di titik j harus lebih dari waktu kendaraan mulai dilayani di titik sebelumnya ditambah dengan waktu service di node i dan waktu perjalanan di dari node i ke node j. Kendala Pers.10 memastikan bahwa total waktu tempuh kendaraan dalam satu hari tidak melebihi jam tutup depot. Kendala Pers.11 menghitung total waktu tempuh kendaraan. Kendala Pers.12 memastikan bahwa kendaraan kembali ke depot sebelum mencapai spoilage time darah. Kendala Pers.13 dan Pers.14 merupakan kendala yang mengeliminasi adanya sub-tour untuk setiap kendaraan. Kendala Pers.15 dan Pers.16 merupakan kendala bahwa hasil dari variabel keputusan adalah bilangan integer 0 dan 1 .

\section{Hasil dan Pembahasan}

Dari model matematis yang telah dibangun kemudian akan dilakukan verifikasi model matematis dengan menggunakan software LINGO dengan perangkat Lunak Windows 7 , Intel (R) Core(TM) i5-2320 CPU @ 3.00 Ghz dan 2 GB RAM. Verifikasi dilakukan dengan melakukan simulasi penyelesaian kasus Blood Mobile Collection Routing. Untuk melakukan simulasi, peneliti membangkitkan data hipotetik untuk kasus kecil yang didasarkan dari data vehicle routing problem. Dalam penelitian ini dibangkitkan 8 dataset dengan karakteristik yang berbeda-beda untuk masingmasing kasusnya. Perbedaan dari setiap kasus ada di jumlah titik yang digunakan, lokasi koordinat tiap nodes, waktu singgah pada tiap titik, kapasitas kendaraan, dan umur darah yang digunakan.

Untuk dataset BMCRP_1 hingga BMCRP_4 digunakan 5 titik yang akan dikunjungi, sedangkan BMCRP_5 hingga BMCRP_8 digunakan 8 titik yang akan dikunjungi. Data set BMCRP_1 dan BMCRP_2 mempunyai matriks jarak, supply rate, dan time windows yang sama, yang membedakan adalah service time dan kapasitas kendaraannya Data set BMCRP_1 dan BMCRP_2 mempunyai matriks jarak, supply rate, dan time windows yang sama, yang membedakan adalah service time dan kapasitas kendaraannya. Data set BMCRP_3 dan BMCRP_4 mempunyai matriks jarak, supply rate, kapasitas kendaraan dan time windows yang sama, yang membedakan adalah service time-nya. Data set BMCRP_5 dan BMCRP_6 mempunyai matriks jarak, 
supply rate, dan time windows yang sama, yang membedakan adalah service time dan kapasitas kendaraannya. Data set BMCRP_7 dan BMCRP_8 mempunyai matriks jarak, supply rate, kapasitas kendaraan dan time windows yang sama, yang membedakan adalah service time-nya.

Dari data set yang telah dibangkitkan, kemudian dilakukanlah running pada software LINGO untuk mencari solusi rute optimalnya. Tabel 1 merupakan rekapitulasi hasil rute optimal yang didapatkan.

Tabel 1. Hasil Rute Optimal

\begin{tabular}{|c|c|c|l|}
\hline No & Dataset & $\begin{array}{c}\text { Total } \\
\text { Jarak }\end{array}$ & \multicolumn{1}{|c|}{ Rute Optimal } \\
\hline 1 & BMCRP_1 & 8955,78 & $\begin{array}{l}\text { Kendaraan 1 = 0-4-0 } \\
\text { Kendaraan 2 = 0-5-3-2-1-0 }\end{array}$ \\
\hline 2 & BMCRP_2 & 10188,20 & $\begin{array}{l}\text { Kendaraan 1 = 0-3-2-1-0 } \\
\text { Kendaraan 2 = 0-5-4-1 }\end{array}$ \\
\hline 3 & BMCRP_3 & 151,36 & $\begin{array}{l}\text { Kendaraan 1 = 0-2-0 } \\
\text { Kendaraan 2 = 0-5-1-3-4-0 }\end{array}$ \\
\hline 4 & BMCRP_4 & 230,07 & $\begin{array}{l}\text { Kendaraan 1 = 0-2-4-0 } \\
\text { Kendaraan 2 = 0-1-0 } \\
\text { Kendaraan 3 = 0-5-3-0 }\end{array}$ \\
\hline 5 & BMCRP_5 & 13776,73 & $\begin{array}{l}\text { Kendaraan 1 = 0-8-6-1-2-0 } \\
\text { Kendaraan 2 = 0-5-3-7-4-0 }\end{array}$ \\
\hline 6 & BMCRP_6 & 16460,07 & $\begin{array}{l}\text { Kendaraan 1 = 0-3-2-1-0 } \\
\text { Kendaraan 2 = 0-8-6-0 } \\
\text { Kendaraan 3 = 0-5-7-4-0 }\end{array}$ \\
\hline 7 & BMCRP_7 & 235,79 & $\begin{array}{l}\text { Kendaraan 1 = 0-8-5-3-1-0 } \\
\text { Kendaraan 2 = 0-2-6-0 } \\
\text { Kendaraan 3 = 0-7-4-0 }\end{array}$ \\
\hline 8 & BMCRP_8 & 247,53 & $\begin{array}{l}\text { Kendaraan 1 = 0-2-6-4-0 } \\
\text { Kendaraan 2 = 0-5-3-0 } \\
\text { Kendaraan 3 = 0-7-8-1-0 }\end{array}$ \\
\hline
\end{tabular}

Dari Tabel 1, dapat diketahui bahwa model matematis yang dikembangkan telah terverifikasi dan tervalidasi serta berhasil mendapatkan hasil rute yang optimal beserta total jaraknya. Verifikasi dilakukan dengan mengecek satu per satu constraint dan objective function yang dituliskan pada program LINGO apakah sudah sesuai dengan permasalahan yang ingin diselesaikan. Untuk proses validasi dilakukan dengan mengecek secara manual hasil rute optimal yang didapatkan. Dari hasil pengecekan tersebut, didapatkan hasil bahwa rute optimal yang dihasilkan sudah tidak ada yang melanggar batasan-batasan yang ada, baik dari segi umur darah, kapasitas kendaraan, maupun jam buka-tutup masing-masing lokasi. Dari segi waktu penyelesaiannya, LINGO berhasil mendapatkan solusi optimal dari masingmasing kasus dalam waktu kurang dari 1 menit.

\section{Simpulan dan Saran}

Penelitian ini mengembangkan suatu model matematis untuk penyelesaian kasus pengumpulan darah secara mobile yang disebut Blood Mobile Collection Routing Problem (BMCRP). BMCRP merupakan sebuah permasalahan bagaimana suatu kendaraan pengumpul darah mengunjungi setiap tempat pengumpulan darah secara mobile untuk meminimasi jarak yang ditempuh dengan mempertimbangkan batasan-batasan yang ada. Model matematis yang telah dibangun kemudian diverifikasi dan divalidasi dengan software LINGO. Untuk keperluan pengujian model, maka dibangkitkanlah data hipotetik untuk kasus kecil. Dari hasil simulasi pada software LINGO, dapat diketahui bahwa model matematis yang dikembangkan telah terverifikasi dan tervalidasi serta mendapatkan hasil rute yang paling optimal dengan tidak melanggar batasan yang ada. Untuk penelitian selanjutnya dapat berfokus untuk mengembangkan metode penyelesaian selain metode eksak seperti metode metaheuristik agar dapat menyelesaikan kasus BMCRP dalam skala yang lebih besar.

\section{Daftar Pustaka}

American-Association-of-Blood-Banks. (2007). The 2007 National Blood Collection And Utilization Survey.

Dantzig, G. B. and J. H. Ramser. (1959). The Truck Dispatching Problem. Management Science 6(1): 80-91.

Doerner, K. F., M. Gronalt, R. F. Hartl, G. Kiechle and M. Reimann. (2008). Exact and heuristic algorithms for the vehicle routing problem with multiple interdependent time windows. Computers \& Operations Research 35(9): 3034-3048.

Dumas, M. B. and M. Rabinowitz. (1977) Policies for Reducing Blood Wastage in Hospital Blood Banks. Management Science 23(10): 1124-1132.

Gunpinar, S. and G. Centeno (2015). "Stochastic integer programming models for reducing wastages and shortages of blood products at hospitals." Computers \& Operations Research 54: 129-141.

Gunpinar, S. and G. Centeno. (2016). An integer programming approach to the bloodmobile routing problem. Transportation Research Part E: Logistics and Transportation Review 86: 94-115.

Iswari, T., Yu, V.F., dan Asih, A.M.S. (2016). A Simulated Anealing Heuristic for Blood Pick-Up Routing Problem. Electronic Thesis 
and Dissertation (ETD) National Taiwan University of Science and Technology. Diakses dari: https://pc01.lib.ntust.edu.tw/ETD-db/ETDsearch/view_etd?URN=etd-0620116133237 [2017, 1 Maret].

Kementerian Kesehatan Republik Indonesia. (2016). Ketersediaan Darah ditentukan partisipasi masyarakat menjadi donor. http://www.depkes.go.id/article/print/160603 00001/ ketersediaan-darah-ditentukanpartisipasi-masyarakat-menjadi-donor.html. , diakses Desember 2016.

Laporte, G. (1992). The Vehicle Routing Problem: An overview of exact and approximate algorithms. European Journal of Operational Research 59(3): 345-358.

Ozener, O. O. and A. Ekici. (2011). Vehicle Routing for Blood Collection. Proceedings of the 2011 Industrial Engineering Research Conference.

Şahinyazan, F. G., B. Y. Kara and M. R. Taner (2015). "Selective vehicle routing for a mobile blood donation system." European Journal of Operational Research 245(1): 22-34.

Solomon, M. M. and J. Desrosiers. (1988). Survey Paper-Time Window Constrained Routing and Scheduling Problems. Transportation Science 22(1): 1-13.

Song, B. D. and Y. D. Ko (2016). "A vehicle routing problem of both refrigerated- and general-type vehicles for perishable food products delivery." Journal of Food Engineering 169: 61-71.
Yi, J. (2003). Vehicle Routing with Time Windows and Time-Dependent Rewards: A Problem from the American Red Cross. Manufacturing \& Service Operations Management. 5(1): 74-77. 
DOI: http://dx.doi.org/10.26593/jrsi.v7i2.2769.65-72

Halaman ini sengaja dikosongkan This page is intentionally left blank 